\title{
$\nabla$
}

\section{Acanthosis nigricans and "tripe palm" as paraneoplastic manifestations of metastatic tumor}

\author{
Acantose nigricante e "palma em tripa" como manifestações paraneoplásicas \\ de tumor metastático
}

\author{
Mariana Carvalho Costa ${ }^{1}$ \\ Maluf Gabbay Belicha ${ }^{1}$
}

\author{
Nayibe Solano Martinez ${ }^{1}$ \\ Fabiano Leal ${ }^{2}$
}

\begin{abstract}
Acanthosis nigricans is a common dermatosis and is most often associated with benign conditions, such as insulin resistance. It is rare as a paraneoplastic marker. As such, it is characterized by sudden onset and rapid dissemination of velvety and hyperchromic skin lesions. The term "tripe palm" refers to exaggeration of the palmar ridge pattern, which resembles the internal surface of the bovine intestinal tract. This is a paraneoplastic marker of high specificity, with $90 \%$ of the cases being associated with malignancy. We report the case of a patient with stage IV ovarian adenocarcinoma presenting acanthosis nigricans and tripe palm. Both findings are closely correlated to the neoplasm course.

Keywords: Acanthosis nigricans; Neoplasm metastasis; Skin manifestations

Resumo: A acantose nigricante é uma dermatose comum, mais frequentemente associada a condições benignas, como resistência periférica à insulina. É rara como marcador paraneoplásico. Como tal, é caracterizada pelo aparecimento repentino e disseminação rápida de lesões cutânas aveludadas e hipercrômicas. O termo "palma em tripa" se refere ao aumento da demarcação do sulcos cutâneos, que se assemelha à face interna do trato intestinal bovino. É um marcador paraneoplásico de alta especificidade, com 90\% dos casos associados à malignidade. Relatamos uma paciente com adenocarcinoma de ovário, estágio IV, apresentando acantose nigricante e "palma em tripa"; ambos achados estão estreitamente relacionados ao curso da neoplasia.

Palavras-chave: Acantose nigricans; Manifestações cutâneas; Metástase neoplásica
\end{abstract}

Acanthosis nigricans is a common dermatosis and is most often associated with benign conditions, such as obesity and insulin resistance. ${ }^{1}$ It is rare as a paraneoplastic marker. However, when related to malignancy, $90-95 \%$ of cases are associated with abdominal cavity adenocarcinomas and, in more than half of them, with gastric tumors. ${ }^{2,3,4}$ The term "tripe palm" refers to exaggeration of palmar and sometimes plantar skin ridges, which resemble the internal surface of the bovine gastrointestinal tract. It is a para- neoplastic marker, with $90 \%$ of the cases being associated with malignancy. In this communication article, we describe acanthosis nigricans as a paraneoplastic marker and highlight the "tripe palm" finding, which is fairly unreported and reveals great specificity for malignancy. ${ }^{3}$

A 57-year-old woman presented skin thickening with exaggerated ridges and hyperpigmentation of the orbicular, perilabial, and cervical regions. The conditions had been present for two years and were associ-

Received on 28.08.2011.

Approved by the Advisory Board and accepted for publication on 25.12.2011.

* Work conducted at Prof. Rubem David Azulay Institute of Dermatology - Rio de Janeiro (RJ), Brazil.

Conflict of interest: None

Financial funding: None

Physician - Graduate student in Dermatology, Prof. Rubem David Azulay Institute of Dermatology (Instituto de Dermatologia Prof. Rubem David Azulay) - Rio de Janeiro (RJ), Brazil.

Dermatologist - Preceptor, General Dermatology Outpatient Clinic, Prof. Rubem David Azulay Institute of Dermatology - Rio de Janeiro (RJ), Brazil. 
ated with weight loss and lumbar pain. Acrochordons were found in the posterior cervical region (Figure 1). The same pattern of lesions was found in the axillary, inframammary and intergluteal regions, groin and vulva. Erythematous coalescent nodules were observed in the vulva (Figure 2). The hands had a velvety appearance, ridged surface, and sharp demarcation of dermatoglyphics (Figure 3). The patient had been diagnosed with endometrioid adenocarcinoma of the ovary 12 years earlier (stage II). At that time, she decided not to follow clinical treatment. Vulvar lesion histopathology demonstrated moderately differentiated adenocarcinoma. Imaging examination revealed pulmonary nodule and voluminous intrapelvic mass. We came to the diagnosis of a metastatic ovarian tumor, with skin implants, pulmonary nodule and rec- tal invasion (stage IV). The patient also presented acanthosis nigricans and "tripe palm" as paraneoplastic markers, which appeared with tumor recurrence and metastasis. She was referred to oncology, subjected to a colostomy, and is currently undergoing palliative chemotherapy.

Acanthosis nigricans associated with neoplasia (ANAN) was first described by two independent observers, Pollitzer and Janovsky, in 1890, in the book "International Atlas of Rare Skin Diseases", edited by Unna. Its pathogenesis is unclear, although an interaction between TGF-alpha and epidermal growth factor receptors is reported. ${ }^{2,5}$ ANAN is often referred to as "malignant acanthosis nigricans", which is an equivocal definition, since this is not a malignant dermatosis by
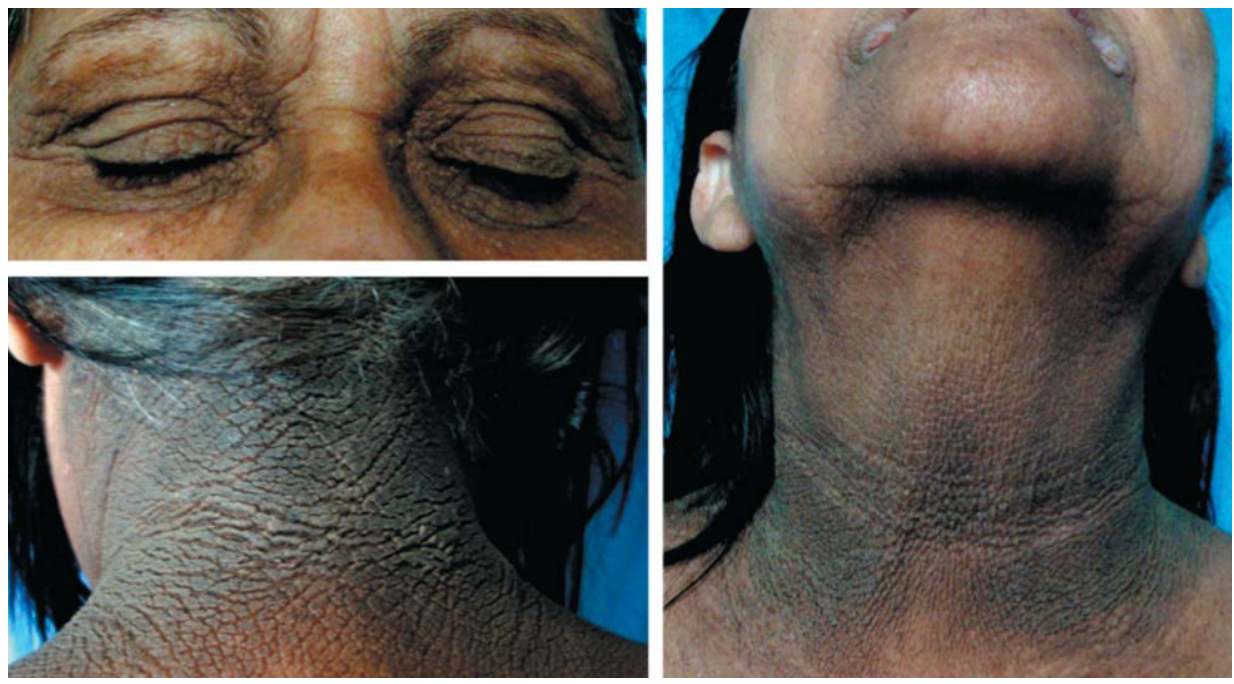

Figure 1: Patient presenting skin thickening with exaggerated ridges and hyperpigmentation of the orbicular, perilabial, and cervical regions
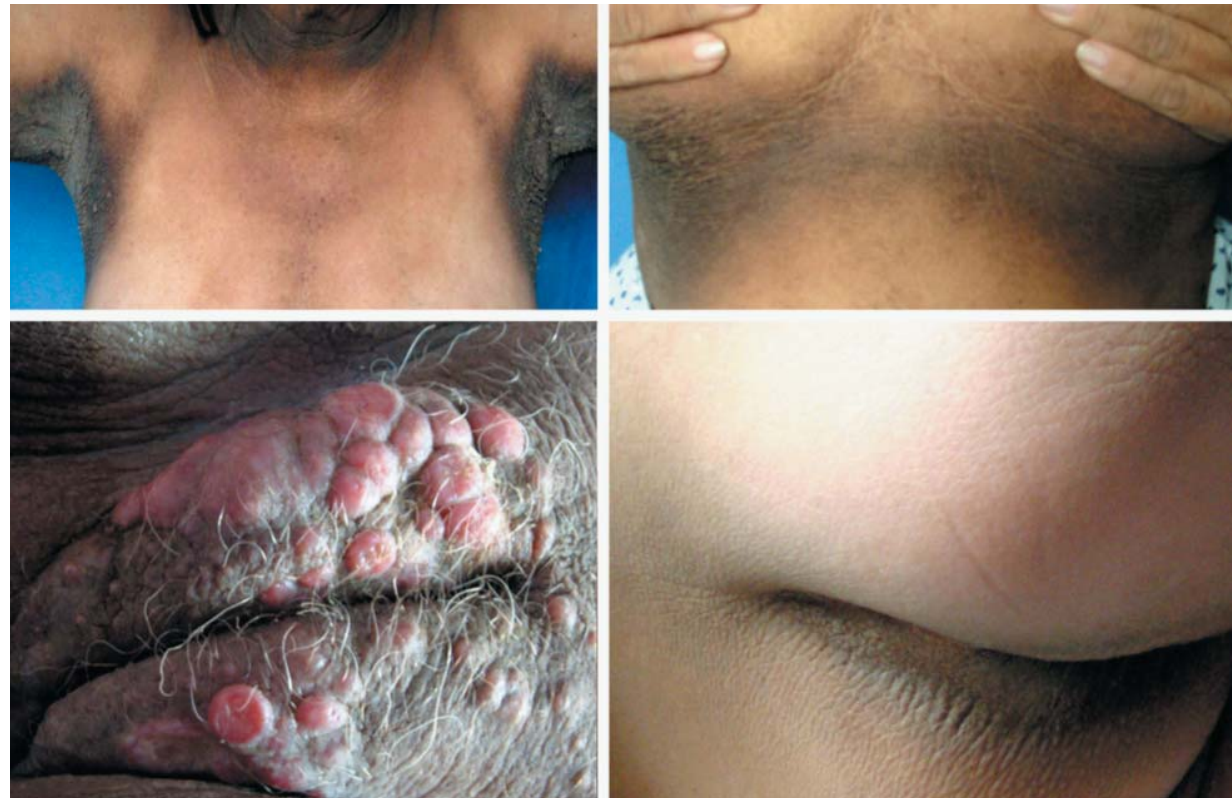

Figure 2: Same pattern of lesions in the axillary, inframammary and intergluteal regions, groin, and vulva. Erythematous nodules, including coalescent ones, observed in the vulva as well 

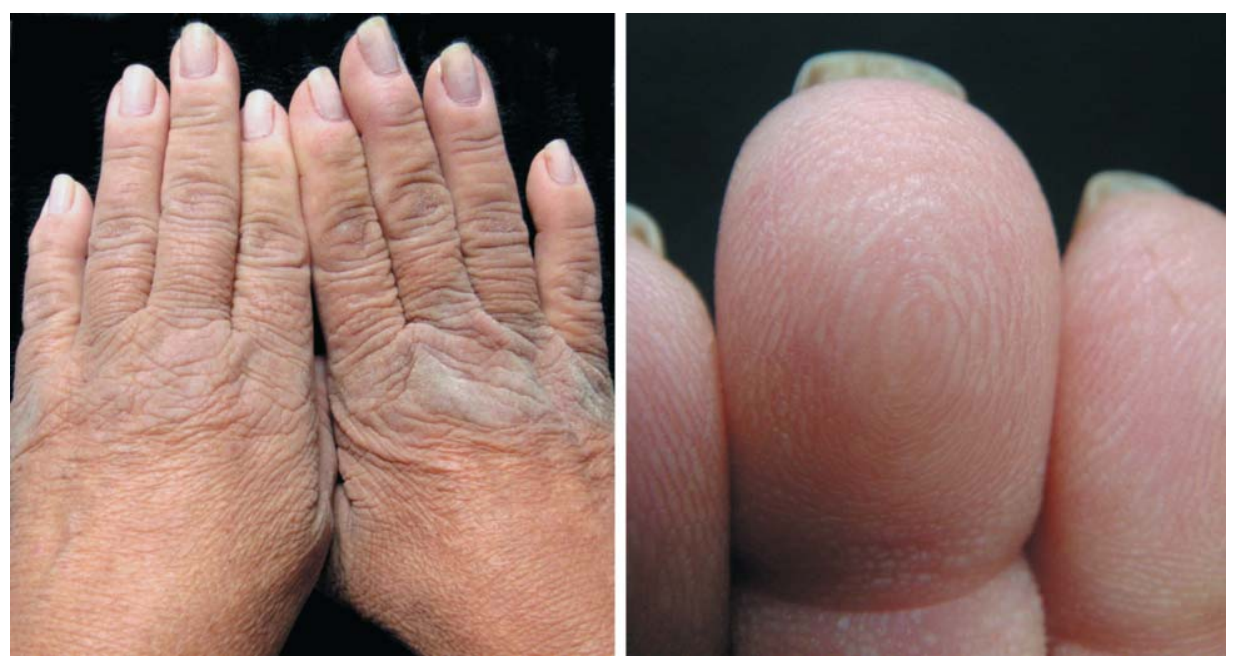

Figure 3: Patient's hands presenting a velvety appearance, ridged surface and sharp demarcation of dermatoglyphics ("tripe palm")

itself, but one associated with malignancy. ${ }^{6}$

The clinical presentation of acanthosis nigricans is characterized by areas of skin thickening with a velvety and hyperpigmented appearance. ${ }^{3}$ It affects body folds, and the increased epidermal proliferation may lead to papilloma sprouting. ${ }^{7}$ The same characteristics are found in ANAN, but it has sudden onset and rapid dissemination. ${ }^{1,2}$ In addition to intertriginous areas, it may involve mucosae, lips, areolas, orbicular margins, traumatized areas, and skin metastasis sites. It may appear before $(20 \%)$, at the time of $(60 \%)$, or after (20\%) detection of the primary tumor. ${ }^{1,2,8}$

The diagnosis of any form of acanthosis nigricans is mainly clinical. The histopathology is characterized by hyperkeratosis and papillomatosis. ${ }^{2}$
Treatment and prognosis of ANAN are related to tumor evolution, since the dermatosis and the tumor are likely to follow a parallel course. ${ }^{4,9}$

The term "tripe palm" was formally introduced to the medical literature by Clarke in the 1970s. ${ }^{5}$ Most authors consider "tripe palm" a variant of acanthosis nigricans. More than $90 \%$ of cases are associated with malignancy, particularly lung cancer (if isolated) and, second in frequency, gastric carcinoma (when associated with ANAN). ${ }^{2}$ It may appear before and during the diagnosis of a tumor or its recurrence. Pruritus and watch glass nails may be present. Histopathological analysis, diagnosis, prognosis and treatment are the same as those used for ANAN.

\section{REFERENCES}

1. Boyce S, Harper J. Paraneoplastic dermatoses. Dermatol Clin. 2002;20:523-32.

2. Chung VQ, Moschella SL, Zembowicz A, Liu V. Clinical and pathologic findings of paraneoplastic dermatoses. J Am Acad Dermatol. 2006;54:745-62.

3. Moore RL, Devere TS. Epidermal manifestations of internal malignancy. Dermatol Clin. 2008;26:17-29, vii.

4. Thiers BH, Sahn RE, Callen JP. Cutaneous Manifestations of internal malignancy. CA Cancer J. 2009:59:73-98.

5. Torley D, Bellus GA, Munro CS. Genes, growth factors and acanthosis nigricans. Br J Dermatol. 2002;147:1096-101.

6. Pipkin CA, Lio PA. Cutaneous manifestations of internal malignancies: an overview. Dermatol Clin. 2008;26:1-15, vii.

7. Weger W, Ginter-Hanselmayer G, Hammer HF, Hödl S. Florid cutaneous papillomatosis with acanthosis nigricans in a patient with carcinomas of the lung and prostate. J Am Acad Dermatol. 2007:57:907-8.

8. Lee HW, Suh HS, Choi JC, Lee MW, Choi JH, Moon KC, et al. Hyperkeratosis of the nipple and areola as a sign of malignant acanthosis nigricans. Clin Exp Dermatol. 2005;30:721-2

9. Brinca A, Cardoso JC, Brites MM, Tellechea O, Figueiredo A. Papilomatose cutânea florida e acantose nigricante maligna reveladoras de neoplasia gástrica. An Bras Dermatol. 2011;86:573-7.

How to cite this article: Costa MC, Martinez NS, Belicha MG, Leal F. Acanthosis nigricans and "tripe palm" as paraneoplastic manifestations of metastatic tumor. An Bras Dermatol. 2012;87(3):498-500.

\author{
MAILING ADDRESS: \\ Mariana Carvalbo Costa \\ SHIS QI 17 conj 08 casa 02 - Lago Sul \\ 71645-080 Brasília, DF \\ E-mail address: maricosta133@gmail.com
}

